before students can proceed to further study, but, after that, courses offering different depths of specialization can be followed. All credits for successfully completed courses will be of equal value, eight credits being required for an honours degree, two more than for an ordinary degree. There will probably be continuous assessment of student progress as well as examinations, and certificates will be awarded for each credit obtained. The committee considers that it will be essential to have an efficient student guidance service to advise on the limitations and wide possibilities of the courses and to recommend courses suitable to the various aptitudes and interests of individual students.

Correspondence courses will form the basis of every degree, and viewing-listening centres throughout Britain will have to supplement live broadcasting. The four foundation courses for the four degree "lines" will be broadcast in the first year of the university's life, and will need to be repeated every year to start students off. It will not be possible to broadcast all the component courses every year, but it is hoped that students will be able to obtain the broadcast material by some other means. One contact a week between student and tutor is suggested for foundation courses, but the committee stresses that the subject of contacts must be carefully examined.

The committee considers that other courses-professional, technical and refresher-should be instituted at the opening of the university, some of them with no examinations at the end. The committee adds that "shortage of transmission time of the broadcasting media should not be thought of as an impediment to putting on such courses. Other methods of making them available to potential audiences may very well have been developed by 1970 and should be used."

The university will also encourage other bodies such as local education authorities, extra-mural departments of universities and workers' education associations to organize courses as preparation for the university's own degrees. Regional officers will be appointed to coordinate local efforts.

The planning committee meets at present once a month, but working groups for "ways and means", "students and curriculum" and "constitution and organization" meet once a week for the bulk of the preparatory work. A fourth group is to be set up to consider finance and the costs of decisions that have so far been taken by the committee. With the charter of the university worked out, the constitution and organization group is likely to fade out, and further decisions will be taken by the committee as a whole. The relative merits of opening the university in October or January are at present being discussed, for there could be advantages in beginning the academic year in January and being able to continue through the summer when educational facilities are least used. In organizing local centres for study, the university hopes to pay rent for facilities that are under-used, such as television sets in schools which are not used in the evenings. Library facilities are also being discussed with the appropriate authorities. The 1966 White Paper ( $A$ University of the Air, HMSO, 1s.) stated that an "estimate of the potential audience can only be guesswork". As yet there has been little progress towards translating the guesses into hard figures, but a survey will be carried out this spring. It is expected that students will be older people rather than school leavers.
Finance has yet to be fully investigated, so no figure has yet been set for fees that students will pay. Salaries for academic staff and fees to the $\mathrm{BBC}$ for broadcasting will obviously take large chunks of the budget. Arrangements with the BBC have to be finally agreed, but transmission will be on BBC-2 which should, by the time the university begins, be covering at least 95 per cent of the country. The first courses are not expected to be broadcast in colour. No academic staff have been appointed yet, but the planning committee is thinking in terms of a core of full-time staff with an additional floating staff to help in the production of courses. The posts of vice-chancellor and secretary are the only two advertised so far and applications are under consideration.

\section{Chairman for NERC}

Professor V. C. Wynne-Edwards, regius professor of natural history in the University of Aberdeen, is to be the new chairman of the Natural Environment Research Council in place of Sir Graham Sutton, who retires on September 1 this year. Professor WynneEdwards is well known for his contributions to ecology -particularly for his studies on animal populations. His book, Animal Dispersion in Relation to Social Behaviour, was published in 1962. A fellow of the Royal Society of Edinburgh and of the Royal Society of Canada, he has held appointments at the universities of Bristol and McGill. He has been regius professor of natural history in the University of Aberdeen since 1946 , and it is understood that he will continue to hold this post.

From 1954 to 1957, Professor Wynne-Edwards was a member of the Nature Conservancy; from 1954 to 1966 he was a member of the conservancy's Committee for Scotland, and since 1964 he has been a member of the conservancy's Scientific Policy Committee. He was appointed a member of the Natural Environment Research Council when the council came into being in 1965. From 1965 to 1967 he was chairman of the council's Oceanography and Fisheries Research Grants and Training Awards Sub-Committee. He is at present a member of the council's Oceanography and Fisheries Committee and chairman of its recently formed Freshwater Research Sub-Committee.

\section{Defence Research}

THe House of Commons Select Committee on Science and Technology is now well set into its examination of defence research and development policy in Britain. In fact it has clearly been doing a good deal of work on the quiet, and showed off its progress at the first open meeting this session, when the witnesses came from the Ministry of Technology and the Ministry of Defence. Both ministries had submitted memoranda to the committee and, perhaps revealingly, both were dated October 1967, a time when the select committee had only a notional existence-according to the rules of the House, it has to be re-established at the begin. ning of each session.

One result of this was that the Ministry of Defence document was slightly out of date-perhaps an occupational hazard in a department which on its own admission is used to working on projects with lead times of seven to ten years. Much of the discussion 